\title{
Effects of dietary supplementation of $\beta$-mannanase on performance and egg quality in laying hens
}

\author{
Tung M. Che ${ }^{1 *}$, Nhan T. M. Nguyen ${ }^{1}$, \& Sarah K. Cervantes-Pahm ${ }^{2}$ \\ ${ }^{1}$ Department of Animal Production, Nong Lam University, Ho Chi Minh City, Vietnam \\ ${ }^{2}$ Elanco Animal Health
}

\begin{abstract}
ARTICLE INFO
Research Paper

Received: May 31, 2019

Revised: June 18, 2019

Accepted: June 25, 2019
\end{abstract}

Keywords

$\beta$-mannanase

Egg quality

Isa Brown

Laying hens

Performance

\section{* Corresponding author}

Che Minh Tung

Email: tung.cheminh@hcmuaf.edu.vn

\begin{abstract}
The objective of the experiment was to evaluate effects of dietary supplementation of $\beta$-mannanase (Hemicell ${ }^{\circledR}$ ) on productive performance, egg quality, and fecal moisture content in laying hens from 20 to 35 weeks of age. A total of 375 Isa Brown hens (1615.6 $\pm 76.4 \mathrm{~g} /$ bird) were randomly assigned to 5 treatments in a completely randomized design. The 5 dietary treatments included (1) basal diet with a level of $2800 \mathrm{kcal} \mathrm{ME}$ and no $\beta$-mannanase supplementation (HE, Control), (2) HE +32 units of $\beta$-mannanase $/ \mathrm{g}$ of feed, (3) HE +64 units of $\beta$-mannanase/g of feed, (4) basal diet with a level of $2700 \mathrm{kcal} \mathrm{ME}(\mathrm{LE})+32$ units of $\beta$-mannanase $/ \mathrm{g}$ of feed, and (5) LE +64 units of $\beta$-mannanase $/ g$ of feed. Each treatment was replicated with 25 cages of 3 hens each. All diets were in meal form and contained no antibiotics. The addition of $\beta$ mannanase to HE diets did not affect the egg production of birds as compared with the control $(P>0.05)$. The birds fed LE diets with $\beta$-mannanase had the same egg production as those fed the control and $\beta$-mannanase-supplemented HE diets $(P>0.05)$. Differences in egg weight, egg quality, survival rate, and fecal moisture content were not significant among the treatments $(P>0.05)$. Briefly, addition of $\beta$-mannanase (32 units/g of feed) to LE diets would be beneficial for layers during the early laying period as it resulted in the same performance and egg quality as the HE diet without $\beta$-mannanase supplementation.
\end{abstract}

Cited as: Che, T. M., Nguyen, N. T. M., \& Cervantes-Pahm, S. K. (2019). Effects of dietary supplementation of $\beta$-mannanase on performance and egg quality in laying hens. The Journal of Agriculture and Development 18(3), 41-47.

\section{Introduction}

Nowadays, prices of feed ingredients are increasing due to the increased use of cereals and plant ingredients such as wheat, soybean meal, sesame meal in animal feeding. However, these ingredients contain high levels of indigestible fiber like $\beta$-mannan and non-starch polysaccharides (NSP). According to Reid (1985), $\beta$ mannan and its derivatives ( $\beta$-gaclactomannan or $\beta$-glucomannan) are structural components of the cell wall of the legume family. $\beta$-mannan present in soybean meal has long been known as an anti- nutritional factor. It was reported that $\beta$-mannan reduced egg production, egg weight and daily feed intake in laying hens (Patel \& McGinnis, 1985). It has also been found that a diet containing 2 - $4 \%$ of $\beta$-mannan resulted in decreased growth rate and feed efficiency of broilers (Couch et al., 1967; Ray et al., 1982, Verma \& McNab, 1982). Thus, dietary supplementation of $\beta$-mannanase would optimize the use of soybean meal because $\beta$-mannanase can destroy undigestible $\beta$-mannan in diets and would release more energy to be used for egg production (Tucker et al., 2004; Hsiao et al., 2006). The additional energy re- 
lease would help producers formulate a diet with a reduced energy level without any adverse effects on egg production and thereby reducing feed cost. Thus, the objective of the experiment was to evaluate effects of dietary supplementation of $\beta$-mannanase (Hemicell ${ }^{\circledR}$ ) on productive performance, egg quality, and fecal smoiture content in laying hens from 20 to 35 weeks of age.

\section{Materials and Methods}

\subsection{Experimental design, birds, and housing}

A total of 375 layers (Isa Brown, 19 weeks old) were randomly assigned to 5 treatments in a completely randomized design. The 5 dietary treatments included (1) basal diet with a high energy level of $2800 \mathrm{kcal} \mathrm{ME}$ and no $\beta$-mannanase supplementation (HE, Control), (2) $\mathrm{HE}+32$ units of $\beta$-mannanase/g of feed, (3) HE +64 units of $\beta$-mannanase/g of feed, (4) basal diet with a low energy level of $2700 \mathrm{kcal} \mathrm{ME}(\mathrm{LE})+32$ units of $\beta$-mannanase/g of feed, and (5) LE +64 units of $\beta$-mannanase/g of feed. All diets were in meal form and contained no antibiotics. $\beta$-mannanase used in this experiment was Hemicell ${ }^{\circledR}$ which contained 160 million units $/ \mathrm{kg}$ of product and was provided by Elanco Vietnam. The birds were housed in battery cages with raised wire floors in an open-sided house. Each cage measured $0.4 \mathrm{~m}$ $\times 0.45 \mathrm{~m} \times 0.4 \mathrm{~m}$ in size. Each treatment had 25 replicate cages with 3 birds each. Birds were brought into the housing facility at 17 weeks of age and allowed to adapt to the new environment for 2 weeks $(18,19)$ prior to the commencement of the experiment. The initial body weights of birds were $1615.6 \pm 76.4 \mathrm{~g} /$ bird. The experiment lasted for 16 weeks from 20 to 35 weeks of age.

\subsection{Diet, feeding, and lighting program}

All diets were formulated to meet or exceed the nutritional requirements of layers during the experimental period (NRC, 1994). Hemicell was added on top of basal diets. The ingredient and analyzed chemical composition of the diets with HE and LE levels is presented in Table 1. Diet and feed ingredients were sampled for determination of approximate composition. Diets were mixed at the Applied Research Farm located on the campus of Nong Lam University and labelled accordingly. Feed and water were provided to allow ad libitum access during the entire experiment.
The lighting regime was $16 \mathrm{~h}$ per day and kept constant throughout the experiment. As the natural day length was approximately $12 \mathrm{~h}$ per day, the 4-h artificial light was needed. The lights were daily set to be switched on from 4:00 to 6:00 AM and from 6:00 to 8:00 PM.

\subsection{Chemical analyses}

Feed samples were ground to pass through a 1-mm screen before analysis and analyzed according to the standard methods of AOAC. The feed samples were analyzed in duplicate for DM (930.15), CP (990.03), crude fat (920.39), Ca (968.08), and P (968.08). Amino acids were also analyzed using Phenomenex EZ: faastTM amino acid analysis kit. All analyses were performed by Center of Analytical Services and Experimentation of Ho Chi Minh City, Vietnam. Fecal samples were collected by putting trays under each cage and analyzed for DM according to the AOAC method with modifications. After collection, fecal samples were first dried in an oven at $60^{\circ} \mathrm{C}$ for $24 \mathrm{~h}$, ground to pass through a 1-mm screen and stored in pillboxes. After that, samples were dried at $105^{\circ} \mathrm{C}$ until constant weight.

\subsection{Assessment of productive performance and egg quality}

Egg production, egg weight, and mortality were daily recorded by replicate. Average daily feed intake (ADFI) was weekly determined on a replicate basis. Feed conversion ratio (FCR) was calculated as $\mathrm{kg}$ of total feed intake per hen $/ \mathrm{kg}$ of egg per hen. Production parameters such as egg production, ADFI, and FCR were adjusted for hen mortality. Eggs laid on the last 2 days every 2 weeks were collected for measurement of egg quality. Egg parameters such as egg weight, albumen height, thick albumen weight, thin albumen weight, Haugh units, yolk weight, yolk color, shape index, shell weight, and shell thickness were measured. Albumen height was measured as indicated by Keener et al. (2006). Haugh units were calculated on the input of egg weight and albumen height using the formula of Haugh. Yolk color was determined by using the Roche Color Fan. The egg shape index was calculated by dividing egg length by egg width. Shell thickness was a mean value of measurements at 3 locations on the egg (air cell, equator, and small end), excluding cuticle. 
Table 1. Ingredient and chemical composition of the basal diets

\begin{tabular}{|c|c|c|}
\hline \multirow{2}{*}{ Ingredients, $\%$} & \multicolumn{2}{|c|}{ Basal diets $^{1}$} \\
\hline & Control (High energy, HE) & Low energy (LE) \\
\hline Corn & 45.36 & 47.70 \\
\hline Wheat & 7.00 & 7.00 \\
\hline Rice bran, full fat & 5.80 & 5.80 \\
\hline Soybean meal, $44 \%$ & 26.65 & 26.19 \\
\hline Soybean oil & 3.19 & 1.31 \\
\hline DL-Methionine & 0.154 & 0.154 \\
\hline Salt & 0.34 & 0.34 \\
\hline Choline chloride $50 \%$ & 0.30 & 0.30 \\
\hline Limestone & 9.80 & 9.80 \\
\hline $\mathrm{MCP}$ & 1.30 & 1.30 \\
\hline Vit-Min Premix ${ }^{2}$ & 0.10 & 0.10 \\
\hline Phytase & 0.006 & 0.006 \\
\hline \multicolumn{3}{|c|}{ Analyzed chemical composition } \\
\hline $\mathrm{ME}(\mathrm{kcal} / \mathrm{kg})^{3}$ & 2800 & 2700 \\
\hline $\mathrm{DM}, \%$ & 90.0 & 89.6 \\
\hline Crude fat, $\%$ & 5.92 & 3.97 \\
\hline Crude protein, $\%$ & 18.2 & 18.5 \\
\hline Calcium, \% & 4.30 & 4.12 \\
\hline Total phosphorus, $\%$ & 0.74 & 0.73 \\
\hline Lysine, $\%$ & 1.08 & 1.07 \\
\hline
\end{tabular}

\subsection{Statistical analysis}

Data were analyzed as a completely randomized design by ANOVA using the GLM procedure (SAS Inst. Inc., Cary, NC). The cage was considered the experimental unit. Treatment differences were compared using the least squares means with a Tukey adjustment. The survival rate was compared by $\chi^{2}$ analysis. Treatment effects were considered significant at $P<0.05$.

\section{Results}

\subsection{Productive performance}

Over a 16-week study, there were no differences $(P>0.05)$ among the treatments for egg production, egg weight, and egg mass (Table 2). The egg production of laying hens fed different diets ranged from 92.31 - 92.95\%. Similarly, laying hens consuming LE diets supplemented with 32 units or 64 units of $\beta$-mannanase/g of feed had the same ADFI and FCR as those consuming the control and $\beta$-mannanase-supplemented HE diets
$(P>0.05)$.

\subsection{Egg quality}

With regard to egg quality (Table 3 ), the LE diets supplemented with $\beta$-mannanase did not affect $(P>0.05)$ shape index, Haugh units, albumen weight, yolk weight, and yolk color as compared with the HE diets with or without dietary supplementation of $\beta$-mannanase. A similar trend was also found among the treatments for shell weight $(\mathrm{P}=0.393)$ and shell thickness $(P=0.086)$.

\subsection{Survival rate and fecal moisture content}

The control diet (97.3\%) had the lowest survival rate as compared with the other treatments $(98.7 \%)$, but this difference was not significant $(P=0.845 ;$ Figure 1$)$. Similarly, there were no differences in the fecal moisture content among the treatments $(P=0.756$; Figure 2$)$. The fecal moisture content of layers in all treatments ranged from $78.0-78.7 \%$. 
Table 2. Effects of dietary supplementation of $\beta$-mannanase on reproductive performance of Isa Brown layers from 20 to 35 weeks of age

\begin{tabular}{|c|c|c|c|c|c|c|c|}
\hline \multirow{2}{*}{ Item } & \multicolumn{5}{|c|}{ Dietary treatments 1} & \multirow{2}{*}{ SEM } & \multirow{2}{*}{$P$} \\
\hline & $\mathrm{A}$ & B & $\mathrm{C}$ & $\mathrm{D}$ & $\mathrm{E}$ & & \\
\hline Egg & 92.54 & 92.31 & 92.95 & 92.39 & 92.59 & 0.907 & 0.989 \\
\hline Egg & 54.20 & 53.51 & 53.98 & 54.08 & 53.77 & & 0.631 \\
\hline Egg & 50.16 & 49.42 & 50.18 & 49.94 & 49.78 & 5 & 0.887 \\
\hline $\mathrm{ADl}$ & 100.05 & 98.59 & 98.22 & 98.91 & 100.74 & 49 & 0.404 \\
\hline $\mathrm{FCR}, \mathrm{kg} / \mathrm{kg}^{2}$ & 2.000 & 1.998 & 1.957 & 1.982 & 2.024 & 0.026 & 0.464 \\
\hline
\end{tabular}

${ }^{1} 25$ replicate cages/treatment; 3 birds/cage; A: Control diet (no $\beta$-mannanase, high energy-HE); $\mathrm{B}$ : $\mathrm{HE}+32$ units of $\beta$-mannanase/g of feed ( $0.02 \%$ Hemicell); C: $\mathrm{HE}+64$ units of $\beta$-mannanase $/ \mathrm{g}$ of feed $(0.04 \%$ Hemicell); D: Low energy diet (LE) +32 units of $\beta$-mannanase/g of feed $(0.02 \%$ Hemicell); E: LE +64 units of $\beta$-mannanase/g of feed (0.04\% Hemicell)

${ }^{2} \mathrm{~kg}$ of feed per $\mathrm{kg}$ of egg mass.

Table 3. Effects of dietary supplementation of Hemicell on egg quality of Isa Brown layers from 20 to 35 weeks of age ${ }^{1}$

\begin{tabular}{|c|c|c|c|c|c|c|c|}
\hline \multirow{2}{*}{ Indicator $^{2}$} & \multicolumn{5}{|c|}{$\overline{\text { Dietary treatments }}{ }^{2}$} & \multirow{2}{*}{ SEM } & \multirow{2}{*}{$P$} \\
\hline & $\mathrm{A}$ & $\mathrm{B}$ & $\mathrm{C}$ & $\mathrm{D}$ & $\mathrm{E}$ & & \\
\hline Shape index & 0.790 & 0.787 & 0.784 & 0.789 & 0.787 & 0.002 & 0.462 \\
\hline Haugh units & 79.32 & 78.39 & 78.70 & 79.31 & 78.02 & 0.120 & 0.598 \\
\hline Thick albumen weight, $\%$ & 30.21 & 30.21 & 30.15 & 30.36 & 29.24 & 0.370 & 0.316 \\
\hline Thin albumen weight, $\%$ & 32.89 & 32.93 & 32.97 & 33.13 & 33.91 & 0.340 & 0.293 \\
\hline Yolk weight, $\%$ & 24.59 & 24.72 & 24.66 & 24.22 & 24.62 & 0.170 & 0.357 \\
\hline Yolk color & 4.40 & 4.41 & 4.43 & 4.46 & 4.46 & 0.060 & 0.200 \\
\hline Shell weight, \% & 12.31 & 12.14 & 12.23 & 12.29 & 12.23 & 0.060 & 0.393 \\
\hline Shell thickness, mm & 0.357 & 0.354 & 0.362 & 0.362 & 0.358 & 0.002 & 0.086 \\
\hline
\end{tabular}

${ }_{2} 25$ replicate cages/treatment; 3 birds/cage.

2 Mean values of 8 measurements (weeks 21, 23, 25, 27, 29, 31, 33 \& 35) for each replicate; A: Control diet (no antibiotic, no $\beta$-mannanase, high energy-HE); B: HE +32 units of $\beta$-mannanase/g of feed $(0.02 \%$ Hemicell); C: HE +64 units of $\beta$-mannanase/g of feed $(0.04 \%$ Hemicell); D: Low energy diet (LE) +32 units of $\beta$-mannanase/g of feed (0.02\% Hemicell); E: LE +64 units of $\beta$-mannanase/g of feed (0.04\% Hemicell).

\section{Discussion}

Over the experimental period, laying hens fed the $\beta$-mannanase-supplemented LE diets had the same productive performance as those fed the control or $\beta$-mannanase-supplemented $\mathrm{HE}$ diets. These findings agree with those of previous studies. Jackson et al. (2004) reported that laying hens fed a LE diet (a reduction by 100 $\mathrm{kcal} / \mathrm{kg})$ supplemented with $\beta$-mannanase (110 units/g) had the same egg production and egg weight as those fed a diet with a typical energy level without $\beta$-mannanase supplementation. Likewise, Maureen (2014) found that diets with $2766 \mathrm{kcal} \mathrm{ME} / \mathrm{kg}$ and supplemented with $\beta$ mannanase $(0.04 \%$ Hemicell) did not affect the egg production and egg weight of layers as compared with those containing $2866 \mathrm{kcal} \mathrm{ME} / \mathrm{kg}$ and no $\beta$-mannanase. These positive effects may be due to the $\beta$-mannanase present in Hemicell which can degrade $\beta$-mannan in feed to release more energy for egg production of layers (Nadeem et al., 2005; Bharathidhasan et al., 2008).

The LE diets supplemented with $\beta$-mannanase did not also cause any adverse effects on ADFI and FCR as compared with the control. This indicates the efficiency of $\beta$-mannanase in improving the nutrient digestion and absorption as the ADFI of hens was not different among the treatments. According to Azarfar (2013), a diet supplemented with $\beta$-mannanase increased the crude protein digestibility of broilers. Wu et al. (2005) and Maureen (2014) found that $\beta$ mannanase supplementation improved the energy utilization of a corn-soybean meal-based diet for layers. Briefly, addition of $\beta$-mannanase to a layer diet at the studied levels would be beneficial as it helps uplift the dietary level of energy by 100 $\mathrm{kcal} / \mathrm{kg}$ of feed.

In addition, laying hens fed the LE diets with $\beta$-mannanase supplementation had the same egg quality as those fed the other diets. This observa- 


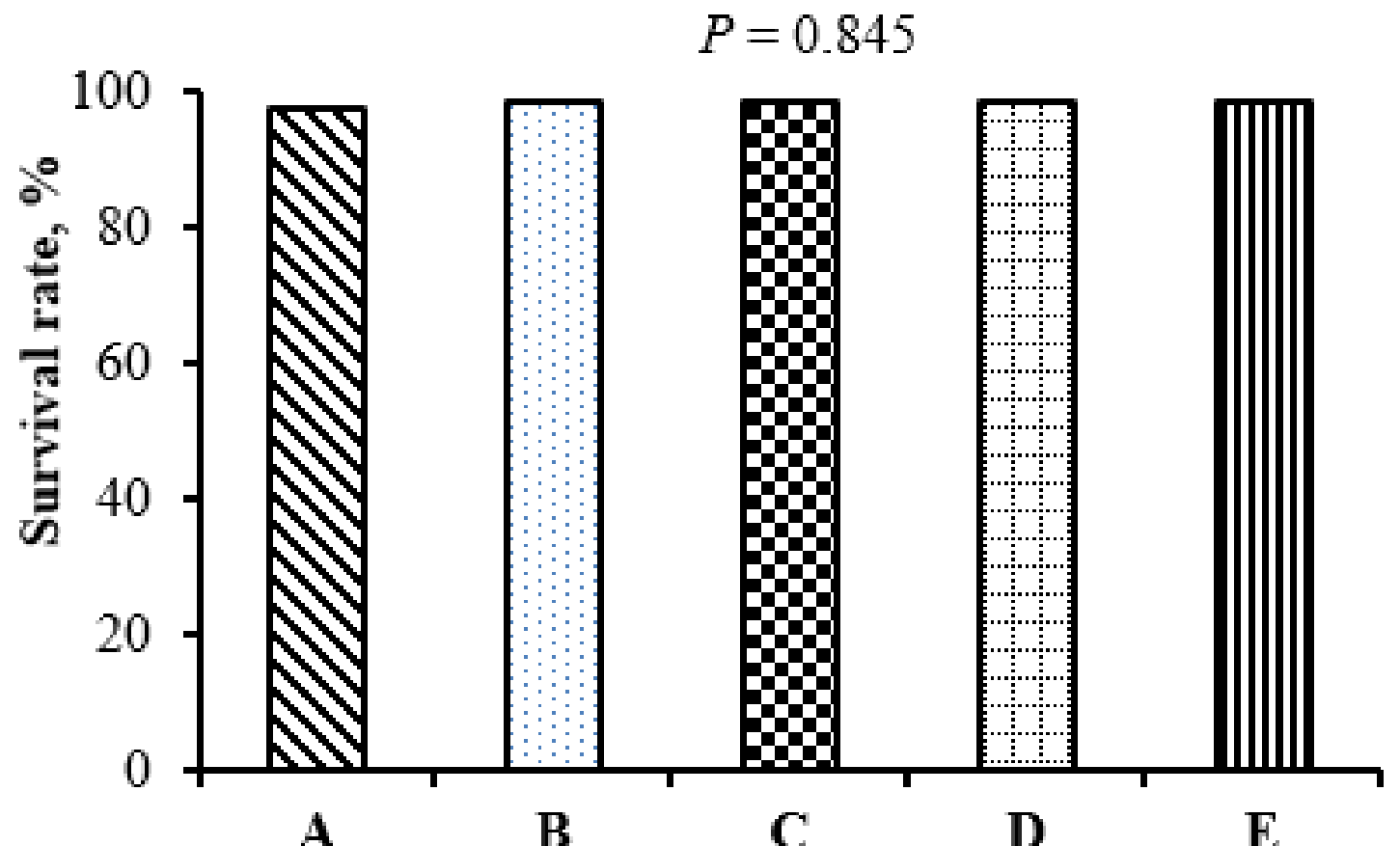

Figure 1. Effects of dietary supplementation of Hemicell on survival rate of Isa Brown layers from 20 to 35 weeks of age. There were 75 birds per treatment. A: Control diet (no antibiotic, no $\beta$-mannanase, high energy$\mathrm{HE})$; $\mathrm{B}: \mathrm{HE}+32$ units of $\beta$-mannanase/g of feed $(0.02 \%$ Hemicell $)$; $\mathrm{C}: \mathrm{HE}+64$ units of $\beta$-mannanase/g of feed $(0.04 \%$ Hemicell); D: Low energy diet (LE) +32 units of $\beta$-mannanase $/ \mathrm{g}$ of feed $(0.02 \%$ Hemicell); E: $\mathrm{LE}+64$ units of $\beta$-mannanase/g of feed ( $0.04 \%$ Hemicell).

tion on the enzyme effect in the present experiment is consistent with those of previous studies. For example, Ehsani \& Torki (2010) found that Hemicell added to a diet of Lohnman laying hens at a dose of $0.06 \%$ did not improve the percentage of eggshell thickness. Torki et al. (2014) also reported that addition of $0.06 \%$ Hemicell to diets did not affect the the percentage of eggshell and eggshell thickness of Hy-line layers. Further, it was found that the egg yolk color scores were relatively low across the treatments, ranging from $4.40-4.60$. This may be explained by the fact that all diets do not contain synthetic pigments, so the formation of egg yolk color is mainly affected by the pigment from corn. According to Cho et al. (2013), when using natural feed ingredients like corn and wheat, the egg yolk color ranges from 4.8 - 5.9 depending on their quality.

$\beta$-mannanase has been assumed to reduce the intestinal viscosity through breaking down large molecules of $\beta$-mannan into smaller compounds, thereby leading to a reduction of fecal moisture contents. This effect can be seen only when in- gredients high in $\beta$-mannans, such as guar meal, palm kernel cake, and copra meal are included in a diet (Lee et al, 2013). The results of our experiment showed no differences in the fecal moisture content among the treatments. Rehman et al. (2016) reported that the effectiveness of $\beta$ mannanase was relatively low in a diet with ingredients containing low levels of $\beta$-mannan such as soybean meal and rice bran. It was shown that the $\beta$-mannan amount varied from $30-35 \%$ in palm kernel cake, 25 - 30\% in copra meal, and $3-9 \%$ in guar meal, whereas there was 1.02 $1.50 \% \beta$-mannan in dehulled soybean meal and $1.17-2.12 \%$ in hulled soybean meal (Dierick, 1989; Hsiao et al., 2006). Furthermore, feeding LE diets with $\beta$-mannanase supplementation did not cause any detrimental effects on health of layers as evidenced by a high survival rate of $98.7 \%$. $\mathrm{Wu}$ et al. (2005) also showed that the survival rate of Hy-Line W36 layers fed an LE diet (2831 kcal ME $/ \mathrm{kg}$ ) with or without $\beta$-mannanase supplementation was not different from that of layers fed an $\mathrm{HE}$ diet (2951 kcal ME/kg) in the 


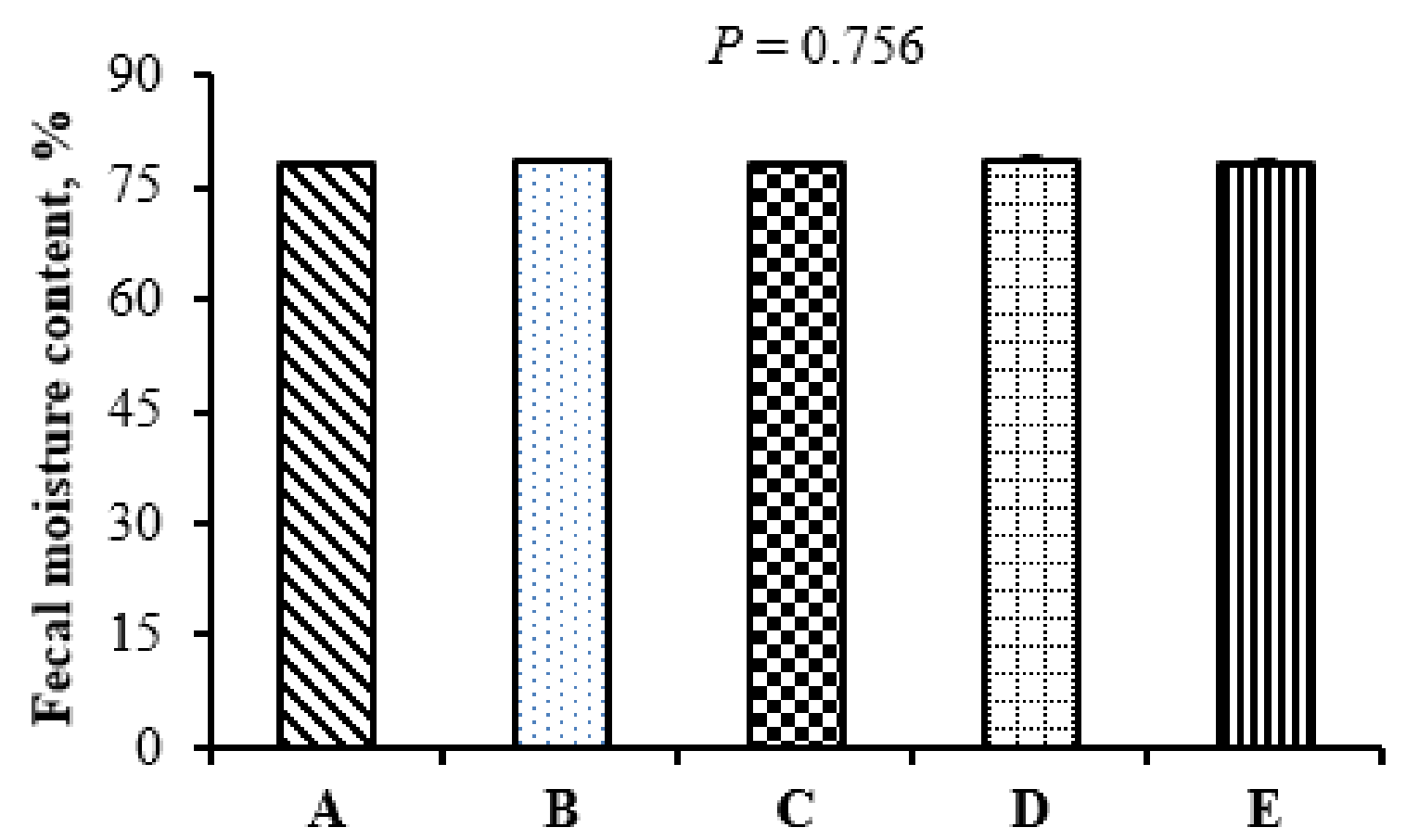

Figure 2. Effects of dietary supplementation of Hemicell on fecal moisture content of Isa Brown layers from 20 to 35 weeks of age. Mean values of 4 measurements (weeks 23, 27, 31, and 35 for each treatment. A: Control diet (no antibiotic, no $\beta$-mannanase, high energy-HE); B: HE +32 units of $\beta$-mannanase/g of feed (0.02\% Hemicell); C: HE + 64 units of $\beta$-mannanase/g of feed (0.04\% Hemicell); D: Low energy diet (LE) +32 units of $\beta$-mannanase/g of feed ( $0.02 \%$ Hemicell); E: LE +64 units of $\beta$-mannanase/g of feed $(0.04 \%$ Hemicell).

absence of $\beta$-mannanase. Briefly, addition of $\beta$ mannanase to diets with LE or HE levels did not affect the fecal smoiture content and survival rate of laying hens from 20 - 35 weeks of age.

\section{Conclusions}

Layers fed the low energy diets with $\beta$ mannanase supplementation performed equally as those fed the high energy diet without $\beta$ mannanase supplementation. No added benefits were obtained when a low enrgy diet was supplemented with 64 units of $\beta$-mannanase/g of feed. This indicates that a dietary supplementation of 32 units of $\beta$-mannanase/g of feed would be beneficial for layers during the early laying period as it uplifted $100 \mathrm{kcal}$ of ME per $\mathrm{kg}$ of feed without affecting the performance and egg quality of layers.

\section{Conflicts of interest}

The authors declare no conflicts of interest.

\section{Acknowledgements}

The authors wish to thank Elanco. This project would not have been possible without Elanco's funding and the support of the Applied Research Farm and Department of Animal Production, Nong Lam University-Ho Chi Minh City.

\section{References}

AOAC Int. (Association of Official Analytical Chemists International). (2005). Official Methods of Analysis. $18^{\text {th }}$ ed. AOAC Int., Arlington, VA.

Azarfar, A. (2013). Effect of hemicell enzyme on the performance, growth parameter, some blood factors and ileal digestibility of broiler chickens fed corn/soybeanbased diets. Journal of Cell and Animal Biology 7(7), 85-91. 
Bharathidhasan, A., Chandrasekaran, D., Natarajan, A., Ravi, R., Viswanathan, K., \& Ezhilvalavan, S. (2008). Non-Starch polysaccharides and phytate phosphorus content of commonly available poultry feed ingredients. Tamilnadu Journal of Veterinary and Animal Sciences 4(6), 219-223.

Cho, J. H., Zhang, Z. F., \& Kim. I. H. (2013). Effects of canthaxanthin on egg production, egg quality and egg yolk color in laying hens. Journal Agricultural Science 5(1), 269-274.

Couch, J. R., Bakshi, Y. K., Ferguson, T. M., Smith, E. B., \& Gregor, C. R. (1967). The effect of processing on the nutritional value of guar meal for broiler chicks. British Poultry Science 8(4), 243-250.

Dierick, N. A. (1989). Biotechnology aids to improve feed and feed digestion: Enzyme and fermentation. Archives of Animal Nutrition 39(3), 241-261.

Ehsani, M., \& Torki, M. (2010). Effects of dietary inclusion of guar meal supplemented by $\beta$-mannanase on performance of laying hens, egg quality characteristics and diacritical counts of white blood cells. American Journal of Animal and Veterinary Sciences 5(4), 237243.

Hsiao, H. Y., Anderson, D. M., \& Dale, N. M. (2006). Levels of $\beta$-Mannan in soybean meal. Poultry Science 85(8), 1430-1432.

Jackson, M. E, Geronian, K., Knox, A., McNab, J., \& McCartney, E. (2004). A dose-response study with the feed enzyme beta-mannanase in broilers provided with corn-soybean meal based diets in the absence of antibiotic growth promoters. Poultry Science 83(12), 19921996.

Keener, K. M., McAvoy, K. C., Foegeding, J. B., Curtis, P.A., Anderson, K. E., Osborne, J. A., \& Bush, D. J. (2006). Effect of testing temperature on internal egg quality measurements. Poultry Science 85(2), 550-555.

Lee, J. Y, Kim, S. Y, Lee, J. H., Lee, J. H., \& Ohh. S. J. (2013). Effect of dietary $\beta$-mannanase supplementation and palm kernel meal inclusion on laying performance and egg quality in 73 weeks old hens. Journal Animal Science Technology 55(2), 115-122.

Maureen, K. C. (2014). Effects of $\beta$-Mannanase on nutrient utilization and peformance of laying chicken (Unpublished master's thesis). University of Nairobi, Nairobi, Kenya.
Nadeem, M. A., Anjum, M. I., Khan, A. G., \& Azim, A. (2005). Effect of dietary supplementation of non-starch polysaccharide degrading enzymes on growth performance of broiler chicks. Pakistan Veterinary Journal 25(4), 183-188.

Patel, M. B., \& McGinnis, J. (1985). The effect of autoclaving and enzyme supplementation of guar meal on the performance of chicks and laying hens. Poultry Science 64(6), 1148-1156.

Ray S., Pubols, M. H., \& McGinnis, J. (1982). The effects of purified guar degrading enzyme on chick growth. Poultry Science 61(3), 488-494.

Rehman, Z. U., Aziz, T., Bhatti, S. A., Ahmad, G., Kamran, J., Umar, S., Meng, C., \& Ding, C. (2016). Effect of $\beta$-mannanase on the performance and digestibility of broilers. Asian Journal Animal and Veterinary Advances 11(7), 393-398.

Reid, J. S. G. (1985). Cell Wall Storage Carbohydrates in seeds-biochemistry of the seed gums and hemicelluloses. Advances in Botanical Research 11, 125-155.

Torki, M., Zangiabadi, H., \& Ghasemi, H. A. (2014). Effects of enzyme supplementation on productive performance and egg quality of laying hens fed diets containing graded levels of whole date waste. Poultry Science 2(2), 139-151.

Tucker, M. P., Nagle, N. J., Jennings, E. W., Aden, A., Nguyen, Q. A., Kim, K. H., \& Noll, S. L. (2004). Conversion of distiller's grain into fuel alcohol and a higher value animal feed by dilute-acid pretreatment. Applied Biochemistry and Biotechnology 115(1-3), 1139-1159.

Verma, S. V. S., \& McNab, J. M. (1982). Guar meal in diets for broiler chickens. British Poultry Science 23(2), 95-105.

Wu, G., Bryant, M. M., Voitle, R. A., \& Roland, D. A. Sr. (2005). Effects of $\beta$ mannanase in corn-soy diets on commercial leghorns in second-cycle hens. Poultry Science 84(6), 894-897. 